\title{
Pengaruh Religiusitas dan Lokasi Terhadap Keputusan Nasabah Memilih BRI Syariah Dalam Transaksi Kredit Kepemilikan Rumah (KPR) Syariah
}

\author{
Hadija Hadija $^{1 *}$,Nuriatullah Nuriatullah ${ }^{2}$, Nurfitriani Nurfitriani ${ }^{3}$ \\ ${ }^{1}$ Jurusan Perbankanb Syariah, Fakultas Ekonomi dan Bisnis Islam, IAIN Palu \\ ${ }^{2}$ Jurusan Perbankan Syariah, Fakultas Ekonomi dan Bisnis Islam, IAIN Palu, \\ ${ }^{3}$ Jurusan Perbankan Syariah, Fakultas Ekonomi dan Bisnis Islam, IAIN Palu
}

ABSTRAK

INFORMASI

ARTIKEL

Penelitian ini bertujuan untuk menganalisis pengaruh religiusitas dan lokasi terhadap keputusan nasabah memilih BRI Syariah dalam transaksi Kredit Kepemilikan Rumah (KPR) Syariah. Teknik pengambilan sampel yang digunakan adalah teknik pengambilan sampel disproporsional sampling dan accidental sampling. Teknik disproporsional sampling yang dipilih dengan sampling jenuh (sensus) yaitu metode penarikan sampel bila semua anggota populasi dijadikan sebagai sampel. Penelitian ini pula menggunakan teknik pengambilan sampel accidental sampling, teknik sampling kebetulan dilakukan apabila pemilihan anggota sampelnya dilakukan terhadap orang atau benda yang kebetulan ada atau dijumpai. Dengan jumlah sampel yang diambil sejumlah 84 nasabah KPR Syariah di BRI Syariah KC Palu Wolter Monginsidi. Dalam melakukan proses data, penelitian ini meggunakan program SPSS 21.0. Penelitian ini menggunakan analisis regresi linear berganda.Berdasarkan hasil penelitian dan hasil analisis data serta pembahasan hasil data disimpulkan bahwa religiusitas berpengaruh positif dan signifikan terhadap keputusan nasabah memilih KPR Syariah dengan nilai $t_{\text {hitung }}>$ $\mathrm{t}_{\text {tabel }}$ yaitu $4.673>1.993$ dengan nilai probabilitas sebesar 0.000 lebih kecil dari 0.05. Lokasi berpengaruh positif dan signifikan terhadap keputusan nasabah memilih KPR Syariah dengan nilai $t_{\text {hitung }}>\mathrm{t}_{\text {tabel }}$ yaitu $3.348>1.993$ dengan nilai probabilitas sebesar 0.001 lebih kecil dari 0.05. 


\section{PENDAHULUAN}

Perumahan merupakan salah satu kebutuhan dasar manusia, baik untuk tempat tinggal, tempat usaha, perkantoran dan lain sebagainya. Namun demikian, belum semua anggota masyarakat dapat menikmati atau memiliki rumah yang layak, sehat, aman dan serasi. Oleh karena itu, agar pembangunan perumahan dan pemukiman terus ditingkatkan untuk menyediakan jumlah perumahan yang makin banyak dengan harga yang terjangkau, terutama oleh golongan masyarakat yang berpenghasilan rendah.

Permintaan akan tempat tinggal dari tahun ketahun terus mengalami peningkatan yang sangat pesat seiring dengan bertambahnya pertumbuhan penduduk. Namun demikian, masih ada kesenjangan (bacgklog) antara kebutuhan akan tempat tinggal dengan ketersediaanya. ${ }^{1}$

Ketimpangan penyediaan perumahan terjadi baik pada sisi suply atau demand. Tingginya permintaan tidak berbanding lurus dengan ketersediaan rumah. Faktor penyebabnya pun juga beragam, mulai dari keterbatasan lahan, kebijakan yang masih kurang efektif, kemampuan pelaku usaha, serta mahalnya pasokan bahan baku menjadi aspek yang menghambat pasokan rumah. Dilihat dari sisi permintaan, faktor pembiayaan yang terbatas menjadi kendala utama. $^{2}$
Sesuai dengan tujuan bangsa Indonesia untuk memenuhi kebutuhan akan tempat tinggal, dalam hal ini pemerintah menyediakan dan menyelenggarakan program yang ditujukan untuk tercapainya tujuan tersebut melalui kredit kepemilikan rumah bagi rakyat atau biasa disebut KPR.

Dalam KPR, konsumen tidak harus menyediakan dana secara tunai untuk membeli rumah, konsumen hanya menyediakan uang muka yang besarnya minimal 5\%-20\% (tergantung ketentuan bank untuk masing-masing nasabah). Hal ini disebabkan KPR memiliki jangka waktu yang panjang dan angsuran yang dibayar dapat diiringi dengan ekpektasi peningkatan penghasilan. $^{3}$

Berbagai fasilitas kemudahan mulai dari proses pengajuan, keringanan biaya administrasi, rendahnya tingkat suku bunga pun dan sebagainya ditawarkan sebagai daya tarik. Sayangnya, suku bunga bank umum yang fluktuatif dan tidak pasti terkadang membuat sebagaian orang merasa khawatir untuk mengambil kredit kepemilikan rumah dari perbankan. Namun kekhawatiran itu seharusnya tidak perlu terjadi jika memanfaatkan fasilitas pembiayaan KPR dari bank syariah atau biasa disebut KPR iB (Islamic Banking).

KPR syariah memang dianggap alternatif pembiayaan bagi seseorang yang 
memiliki rencana untuk mengajukan kredit pembelian tempat tinggal. Produk KPR syariah juga saat ini banyak diminati masyarakat. Sistem kredit tanpa bunga dengan angsuran tetap dianggap menjadi kelebihan dari KPR syariah dibandingkan dengan KPR umum. Seseorang mengambil kredit secara syariah akhirnya merasa lebih tenang karena konsumen akhirnya tidak lagi merasa khawatir jika ditengah masa kredit suku bunga tiba-tiba naik dan menyebabkan ketidak mampuan untuk membayar sisa angsuran. Hal ini dikarenakan secara mendasar perbedaan pokok antara KPR umum dengan KPR syariah terletak pada skema atau akadnya. Jika pada umunya kontrak KPR didasarkan pada suku bunga tertentu yang sifatnya bisa fluktuatif, namun di KPR syariah bisa dilakukan dengan beberapa pilihan skema atau akad sesuai kebutuhan. ${ }^{4}$

Berbeda dengan perjanjian KPR bank umum yang menjadikan suku bunga sebagai acuan, dalam KPR syariah memiliki landasan jual beli dan kerjasama bagi hasil, tidak ada istilah bunga (interest fee) bahkan bunga murah atau rendah dalam KPR syariah. Bank syariah memberikan nilai pinjaman syariah, di mana nilai pinjaman syariah itu sendiri adalah nilai pembelian rumah ditambah margin. Bank syariah memberitahukan berapa margin yang akan diambil oleh bank dan dibebankan kepada nasabah. Dan yang paling penting, margin tersebut diperjelas pada saat awal akad dan tidak akan berubah selama masa kredit. Disamping itu juga nasabah KPR syariah diuntungkan ketika ingin melunasi angsuran sebelum masa kontrak berakhir, karena bank syariah tidak akan mengenakan biaya pinalti dimana harga KPR sudah ditetapkan sejak awal (fix rate).

Pemilihan KPR syariah oleh beberapa orang disebabkan oleh pengaruh religiusitas yang dipercayai. Mayoritas penduduk asli Indonesia beragama Islam, sehingga kiranya sangat memungkinkan untuk suatu bisnis yang berlandaskan syariah. Religiusitas merupakan ketaatan seseorang dalam menjalankan ajaran agamanya, dimana orang yang taat dengan agama akan senantiasa mempertimbangkan segala sesuatunya berdasarkan perintah agamanya, termasukketika seseorang akan melakukan pembelian sebuah produk. Ada beberapa skema atau akad yang digunakan dalam KPR syariah, diantaranya adalah akad jual beli pengadaan (skema Murabahah), akad jual beli pemesanan (Istisna), akad kepemilikan bertahap (Musyarakah Mutanaqisah), dan akad sewa beli IMBT (Ijarah Muntahia Bittamlik). Dari beberapa akad yang ditawarkan, akad jual beli Murabahah paling banyak digunakan oleh bank syariah diIndonesia. $^{5}$

Lokasi perumahan juga menjadi salah 
satu pertimbangan penting bagi nasabah, karena lokasi berpengaruh dengan permintaan KPR syariah yang diajukan oleh nasabah. Jika lokasi perumahan aman, sehat, nyaman, teratur, fleksibel dan jangkauan jarak yang ideal, apabila dijual maka nasabah akan lebih memprioritaskan perumahantersebut.

Sebagai bank komersil tertua, BRI konsisten dengan memberikan pelayanan kepada segmen masyarakat kecil menengah, dan hingga saat ini BRI tetap mampu menjaga komitmen tersebut ditengah kompetisi industry perbankan Indonesia. Dengan dukungan pengalaman dan kemampuan yang berkualiatas dalam memberikan layanan perbankan, terutama pada segmen Usaha Mikro, Kecil dan Menengah (UMKM), BRI mampu mencatat prestasi selama 10 tahun berturut-turut sebagai bank dengan laba terbesar. BRI terus mengembangkan jaringan kerja sehingga kini tercatat sebagai bank terbesar dalam hal jumlah unit kerja di Indonesia, yaitu berjumlah10.396 unit kerja termasuk 3 kantor cabang yang berada di luar negeri, yang seluruhnya terhubung secara real time online.

Sebanyak 50 kantor cabang yang tersebar di wilayah Palu, Poso, Parigi, Donggala dan sekitarnya menggambarkan reputasi BRI menjadi salah satu bank terpercaya serta kompeten untuk mengelola dana masyarakat dan mampu bersaing dalam industry perbankan di Sulawesi Tengah. Untuk wilayah kota Palu sendiri terdapat 24 unit ATM serta 2.367 agen BRILink, ini dapat memudahkan masyarakatsekitar untuk melakukan transaksi keuangan.

BRI Syariah KC Palu Wolter Monginsidi menjadi BRI Syariah pertama dan hingga saat ini masih menjadi kantor cabang satu-satunya BRI Syariah yang terdapat di Sulawesi Tengah. Sesuai dengan visinya yaitu "Menjadi bank ritel modern terkemuka dengan layanan finansial sesuai kebutuhan nasabah dengan jangkauan termudah untuk kehidupan lebih bermakna" menjadi salah satu minat masyarakat khususnya muslim dalam pembiayaan yang masih cenderung memetingkan sisi syariah dalam pemilihan produknya.

Berdasarkan data di BRI Syariah, pada bulan Mei 2018 pertumbuhan visitor paling besar oleh BRIS (55\%), BNIS (42\%), BSM (40\%) dibanding bulan sebelumnya. Distimulus melalui berbagai media mulai dari Maret (April naik 18\%) terkait aksi korporasi pada bulan Mei. Dari Juni ke Juli, 3 bank tersebut mengalami lonjakan visitor. Diperkirakan karena momen Semester pertama 2018, Open Recruitment, dan wisuda Fresh Graduate.

\section{TINJAUAN PUSTAKA}

\subsection{Religiusitas}


Dalam Kamus bahasa Indonesia disebutkan religi adalah sistem kepercayaan dan peribadatan kepada Tuhan. ${ }^{4}$

Religiusitas berasal dari kata religi dari kata latin. Menurut suatu pendapat, asalnya relegere,yang berarti mengumpulkan, membaca. Agama memang kumpulan caracara mengabdi kepada Tuhan dan harus dibaca. Pendapat lain mengatakan, kataitu berasal dari religare yang berarti mengikat. Ajaran-ajaran agama memang memiliki sifat mengikat bagi manusia, yakni mengikat manusia dengan Tuhan. ${ }^{5}$

Agama berasal dari bahasa Arab yang mempunyai dua istilah yaitu addien dan almillah. Addien berarti syari'at dan almillah berarti orang yang melaksanakan ibadah 3) agamanya. Menurut bahasa, kata dien (ديـن) mempunyai bermacam-macam arti, cara atau adat, perhitungan, hari kiamat, undangundang, nasehat, taat atau patuh, agama, mengesakan tuhan, kemenangan, pembalasan, kekuasaan. Dengan demikian unsur-unsur penting yang terdapat dalam agama ialah: ${ }^{7}$

1) Kekuatan gaib: Manusia marasa dirinya lemah dan berhajat pada kekuatan gaib itu sebagai tempat minta tolong. Oleh karena itu, merasa harus mengadakan hubungan 1) baik dengan kekuatan gaib tersebut. Hubungan baik ini dapat diwujudkan dengan mematuhi perintah dan larangan kekuatan gaib itu.
2) Keyakinan manusia bahwa kesejahteraannya di dunia ini dan hidupnya diakhirat tergantung pada adanya hubungan baik dengan kekuatan baik yang dimaksud. Dengan hilangnya hubungan baik itu, kesejahteraan dan kebahagiaan yang dicari akan hilangpula.

Respons yang bersifat emosionil dari manusia. Respons itu bisa mengambil bentuk perasaan takut, seperti yang terdapat dalam agama-agam primitif, atau perasaan cinta, seperti yang terdapat dalam agamaagamamonoteisme

Selanjutnya respons mengambil bentuk cara hidup tertentu bagi masyarakat yang bersangkutan,

Paham adanya yang kudus (sacred) dan suci, dalam bentuk kekuatan gaib, dalam bentuk kitab yang mengandung ajaran-ajaran agama bersangkutan dan dalam bentuk tempat-tempattertentu.

Islam sebagai agama merupakan konsep yang mengatur kehidupan manusia secara komprehensif dan universal, baik dalam hubungan dengan Sang Pencipta (hablum minallah) maupun dalam hubungan sesama manusia (hablum minannas). Ada tiga pilar pokok dalam ajaran Islam, yaitu: ${ }^{8}$

Aqidah, komponen ajaran Islam yang mengatur tentang keyakinan atas keberadaan dan kekuasaan Allah sehingga harus menjadi keimanan seorang muslim manakala melakukan kegiatan berbagai aktivitas di 
muka bumi semata-mata untuk mendapatkan keridaan Allah sebagai khalifah yang mendapat amanah dariAllah;

2) Syariah, komponen ajaran Islam yang mengatur tentang kehidupan seorang $b$. muslim, baik dalam bidang ibadah (hablum minallah) maupun dalam bidang muamalah (hablum minannas) yangmerupakan aktualisasi dari akidah yang menjadi keyakinannya. Adapun muamalah meliputi berbagai bidang kehidupan antara lain yang menyangkut ekonomi atau harta dan perniagaan disebut muamalahmaliyah;

Akhlaq, landasan perilaku dan kepribadian yang akan mencirikan dirinya sebagai seorang muslim yang taat berdasarkansyariah.

Dalam bukunya, American Piety: The Nature of Religius Commitment, C.Y. Glock dan R. Stark menyebut ada lima dimensi religiusitas dalam diri manusia, yaitu: ${ }^{9}$

a. Dimensi keyakinan/ ideologi (ReligiusBelieve)

Dimensi ini menunjukkan pada seberapa tingkat keyakinan muslim terhadap kebenaran ajaran-ajaran agama, terutama yang bersifat fundamental dan dogmatik. Dalam Islam, dimensi ini berkaitan rukun iman yang berisi enam kepercayaan, yaitu percaya dengan keberadaan dan ke-Esaan Allah SWT, percaya terhadap Malikatmalaikat, Rasul-rasul-Nya, Kitab-kitab-Nya, adanya hari kiamat dan qadha serta qadar Allah SWT. Konsep tauhid atau pengakuan akan ke-Esaan Allah SWT menjadi dasar dari dimensiini.

Dimensi praktik (Religius Ractice)

Dimensi ini berkaitan dengan komitmen dan ketaatan terhadap agama yang dianutnya, yang diwujudkan dalam ritual atau peribadatan. Dimensi ini dibagi menjadi dua, yaitu:

1) Ritual, mengacu pada seperangkat tindakan keagamaan formal dan praktikpraktik suci yang mengharapkan pemeluknya melaksanakan. Dalam Islam, bentuk ritual yang dimaksud antara lain: Shalat, puasa, zakat, pergi haji bagi yang mampu, membaca dan mengamalkan AlQur'an, berkurban danlainnya.

2) Ketaatan, ketaatan dan ritual bagaikan ikan dan air. Ketika seseorang telah mengetahui ritual-ritual yang harus dilakukan, maka dapat mungkin ritual itu dilakukan semaksimal mungkin untuk menunjukkan bahwa "saya adalah orang yang taat dan komit padaagama."

3) Dimensi pengalaman (ReligiusFeeling)

Dimensi ini berkaitan dengan seberapa besar tingkat seseorang dalam merasakan pengalaman-pengalaman religinya. Dimensi ini terwujud dalam perasaan bersyukur kepada Allah, percaya kepada Allah akan mengabulkan doa- doa kita, khusyu ketika melaksanakan shalat, perasaan bergetar 
hatinya ketika mendengar ayat-ayat AlQur'an, tertolong dari maut akibat bersedekah, Allah maha memberi rizqi dan lainnya.

4) Dimensi pengetahuan agama (Religius Knowlage)

Dimensi ini menunjukkan pada tingkat pengetahuan dan pemahaman muslim pada ajaran-ajaran agamanya, terutama ajaranajaran pokok yang bermuat dalam AlQur'an. Pemahaman agama dapat dicapai melalui aktivitas rasional empiris maupun tekstual normatif. Pengetahuan agama dapat diperoleh dari membaca buku-buku agama, mendatangi majlis ta'lim atau pengajian, mendengarkan acara keagamaan di radio, melihat tayangan keagamaan di TV dan sebagainya ${ }^{1}$.

5) Dimensi konsekuensi (Religius Effect)

Dimensi ini menunjuk pada seberapa besar perilaku muslim dipengaruhi oleh ajaran-ajaran agama. Dimensi ini tercermin dalam perilaku seseorang yang bertqwa (menjalankan perintah-Nya dan menjauhi larangan-Nya), yang meliputi: perilaku suka menolong, bersedekah, berlaku adil pada orang lain, jujur, tidak melakukan korupsi, tidak minum minuman keras, tidak berjudi,

${ }^{1}$ Nurdin, N., \& Yusuf, K. (2020). Knowledge management lifecycle in Islamic bank: the case of syariah banks in Indonesia. International Journal of Knowledge Management Studies, 11(1), 59-80. doi: 10.1504/ijkms.2020.105073 tidak melakukan prostitusi/ seks bebas, dan sebagainya.

\subsection{Perbankan dalam Konsep Islam}

Pasal 1 angka 2 UU No. 21 Tahun 2008 Tentang Terbankan Syariah, Bank adalah badan usaha yang menghimpun dana dari masyarakat dalam bentuk simpanan dan menyalurkannya kepada masyarakat dalam bentuk kredit dan/atau bentuk lainnya dalam rangka meningkatkan taraf hidup rakyat. ${ }^{10}$

Selanjutnya Pasal 1 angka 2 UU No. 21 Tahun 2008 Tentang Perbankan Syariah, yang dimaksud dengan perbankan syariah adalah segala sesuatu yang menyangkut tentang bank syariah dan Unit Usaha Syariah, mencakup kelembagaan, kegiatan usaha, serta cara dan proses dalam melaksanakan kegiatan usahanya. ${ }^{11}$

Dari segi kelembagaan dan kegiatan usahanya, bank syariah dan bank konvensional tidak banyak bedanya, yang membedakan antara bank konvensional adalah cara dan proses melakukan usahanya, yaitu bank konvensional melakukan kegiatan usahanya berdasarkan prinsip hukum secara konvensional yang pendapatannya berdasarkan sistem bunga (interest), sedangkan bank syariah melakukan kegiatan usahanya berdasarkan prinsip syariah tidak mengenal bunga yang pada dasarnya berdasarkan sistem bagi hasil (profit and losssharing). ${ }^{12}$

Dalam operasionalnya, perbankan 
syariah harus selalu dalam koridor prinsipprinsip sebagai berikut: ${ }^{13}$

1. Keadilan, yaitu pembagian keutungan atas dasar penjualan yang sesuai, dan masing-masing pihak.

1) Kemitraan, yang berarti pemegang saham investor pengguna dana, serta lembaga keuangan itu sendiri sejajar sebagai mitra usaha yang saling bersinergi untuk memperolehkeuntungan.

2) Transparansi, lembaga keungan syariah akan memberikan laporan keuangan terbuka dan berkelanjutan agar investor dapat mengetahui kondisidananya.

3) Universal, yang berarti tidak membedakan suku, agama, ras, dan golongan dalam masyarakat sesuai dengan prinsip Islam sebagai Rahmatan LilAlamin.

Prinsip-prinsip syariah yang dilarang dalam operasional perbankan syariah adalah kegiatan yang mengandung unsur-unsur sebagai berikut: ${ }^{14}$

1) Maisir, menurut istilah maisir berarti memperoleh keuntungan tanpa harus bekerja. Maisir sering dikenal dengan perjudian karena dalam praktik perjudian seseorang dapat memperoleh keuntungan dengan cara mudah. Pelarangan maisir oleh Allah SWT dikarenakan efek negatif maisir. Ketika melakukan perjudian seseorang dihadapkan pada kondisi dapat uang maupun rugi secara abnormal. Suatu saat ketika seseorang beruntung ia mendapatkan keuntungan yang lebih besar ketimbang usaha yang dilakukannya. Sedangkan ketika tidak beruntung seseorang dapat mengalami kerugian yang sangat besar. Perjudian tidak sesuai dengan prinsip keadilan dan keseimbangan sehingga diharamkan dalam sistem keuanganIslam.

2) Gharar, menurut istilah gharar berarti sesuatu yang mengandung ketidakjelasan, pertaruhan atau perjudian. Setiap transaksi yang belum jelas barangnyaatautidakdalamkuasanya(diluarj angkauan)termasukjualbeligharar.

Pelarangan gharar karena memberikan efek negatif dalam kehidupan,gharar merupakan praktik pengembalian keutungan secara bathil.

3) Riba, menurut istilah teknis, riba berarti pengembalian tambahan dari harta pokok atau modal secara bathil. Para ulama sepakat bahwa hukumnya riba adalah haram. Hal ini dikarenakan sumber utama syariah, yaitu Al-Qur'an dan Sunah mengutuk riba. Akan tetapi ada perbedaan terkait dengan makna dari riba atau apa saja yang merupakan riba harus dihindari untuk kesesuaian aktivitas-aktivitas perekonomian dengan ajaran syariah ${ }^{2}$.

\footnotetext{
${ }^{2}$ Nurdin, N., Novia, N., Rahman, A., \& Suhada, R. (2019). Potensi Industri Produk Makanan Halal Di Kota Palu. Jurnal Ilmu Ekonomi dan Bisnis Islam, 1(1), 1-12.
} 


\subsection{Lokasi}

Lokasi merupakan tempat dimana perumahan dapat menjangkau dengan mudah. Lokasi yang strategis membuat konsumen lebih mudah dalam menjangkau dan juga keamanan yang terjamin. Sehingga dengan demikian, ada hubungan antara lokasi yang strategis dengan daya tarik konsumen untuk melakukan pembelian suatu produk. Disamping prasarana lingkungan, lingkungan perumahan sederhana harus dilengkapi pula dengan fasilitas lingkungan seperti fasilitas pendidikan, kesehatan perbelanjaan dan niaga, fasilitas pemerintahan dan pelayanan umum, parkir umum, tempat peribadatan, tempat rekreasi dan kebudayaan serta fasilitas olah raga dan lapangan terbuka. ${ }^{16}$

Dikutip dari skripsi Winda Annisa Cahya Kurniawati, menurut Akhmad ada 3 indikator dari lokasi perumahan antara lain: ${ }^{17}$

a. Letak perumahan yangstrategis.

b. Mempunyai akses terhadap pusatpusatpelayanan.

c. Lokasi perumahan yang mencakup beberapakriteria.

Lokasi tanah harus bebas dari pencemaran air dan pencemaran lingkungan baik berasal dari sumber daya buatan atau sumber daya alam. Dapat menjamin tercapainya tingkat kualitas lingkungan hidup yang sehat bagi pembinaan individu dan masyarakat penghuni. Kondisi tanahnya bebas banjir dan memiliki kemiringan tanah0-

$15 \%$,sehinggadapatdibuatsistemsaluranpemb uanganairhujan(drainase).

\subsection{Keputusan Menjadi Nasabah}

Seperti pengambilan keputusan dalam kehidupan sehari-hari dan kehidupan beroganisasi, keputusan beli pun ditentukan dengan cara memilih tindakan dari dua alternatif pilihan atau lebih. Sejauh mana konsumen memiliki alternatif, tergantung pada sifat pembeliannya. Pada pembelian rutin, alternatif tidak penting lagi; sedangkan dalam pembelian dengan keterlibatan tinggi, kosumen sangat memerlukan informasi untuk mengembangkan altrnatif. ${ }^{21}$

Proses pengambilan keputusan konsumen dipengaruhi oleh faktor-faktor eksternal, seperti informasi pemasaran (product, price, place, promotion) dan lingkungan sosial budaya sebagai input. Dalam proses itu sendiri ada faktor-faktor internal yang berperan, misalnya motivasi, persepsi, pembelajaran, kepribadian, sikap dan pengalaman. Output dari proses ini akan disimpan dalam memori sebagai pengalaman (hasil pembelajaran). Pengambilan keputusan konsumen juga dipengaruhi oleh situasi dimana proses dan perilaku tadi terjadi. Situasi komunikasi, situasi pembelian, situasi penggunaan dan situasi 
penyingkiran produk, semuanya menentukan keputusan beli. Lingkungan fisik, lingkungan sosial, waktu, tujuan pembelian, konsumsi dan mood (suasana hati) tidak dapat diabaikan sebagai unsur-unsur yang sangat berarti dalam keputusan beli. Situasi terakhir adalah situasi ritual yang banyak dimanfaatkan pemasar untuk mempengaruhi perilaku konsumen ${ }^{22}$.

Proses pengembalian keputusan sering melibatkan beberapa keputusan. Suatu keputusan (decision) melibatkan pilihan di antara dua atau lebih alternatif tindakan [atau perilaku]. Keputusan selalu mensyaratkan pilihan di antara beberapa perilaku yang berbeda. ${ }^{23}$

\subsection{Kerangka Pemikiran}

Berdasarkan fenomena yang terjadi saat ini kebutuhan akan tempat tinggal di kota Palu semakin terasa mendesak dikarenakan tiap tahunnya mengalami peningkatan sesuai dengan pertumbuhan pertahunnya. Religiusitas menjadi salah satu pertimbangan pemilihan KPR syariah oleh beberapa orang disebabkan oleh pengaruh kepercayaan, mayoritas penduduk asli Indonesia termasuk kota Palu beragama Islam, sehingga kiranya sangat prospek untuk suatu bisnis yang berlandaskan syariah. Dalam memilih KPR syariah tentu saja lokasi juga sebagai bahan pertimbangan untuk memperkuat keputusan pembelian.
Dekat dengan kawasan industri, memilikifasilitaslengkap dan lainnya menjadi prioritas bagi masyarakat untuk memilih lokasi strategis sesuai kebutuhan yang diinginkan.

Dalam penelitian ini dapat dibuat suatu kerangka pemikiran (gambar 2.3) yang dapat menjadi landasan dalam penelitian ini yang pada akhirnya dapat diketahui variabel mana yang paling dominan dalam mempengaruhi keputusan memilih KPR Syariah. Variabel-variabel penelitian yang digunakan dalam penelitian ini adalah keputusan memilih KPR Syariah sebagai variabel dependen. Sedangkan religiusitas dan lokasi sebagai variabel independen. Kerangka pemikiran dalam penelitian ini secara sistematis dapat digambarkan sebagaiberikut:

Gambar 1. Kerangka Pikir
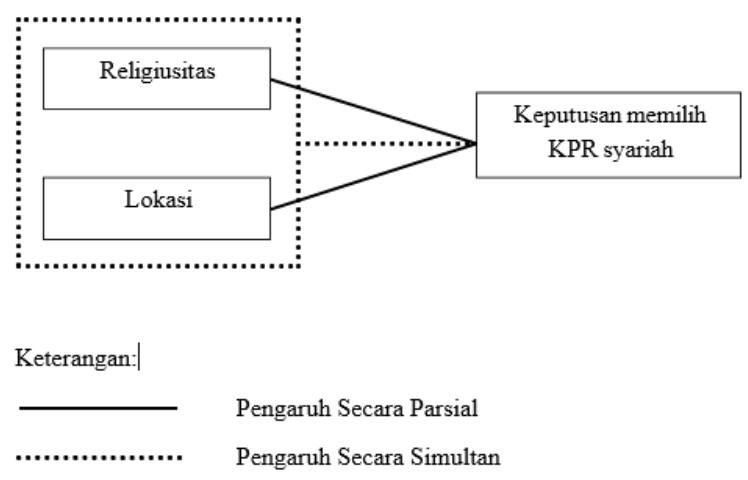

Hipotesis berasal dari kata hypo yang berarti di bawah dan thesa yang berarti kebenaran. Hipotesis dapat didefinisikan sebagai jawaban sementara yang kebenarannya masih harus diuji atau 
rangkuman simpulan teoretis yang diperoleh dari tinjauan pustaka. Hipotesis juga merupakan proposisi yang akan diuji keberlakuannya atau merupakan suatu jawaban sementara atas pertanyaan penelitian. ${ }^{36}$ Berdasarkan latar belakang dan masalah yang dikemukakan, maka hipotesis yangdigunakan:

$\mathrm{H} 1$ = Terdapat pengaruh religiusitas $(\mathrm{X} 1)$ terhadap keputusan memilih KPR Syariah (Y)

$\mathrm{H} 2$ = Terdapat pengaruh lokasi (X2) terhadap keputusan memilih KPR Syariah (Y)

$\mathrm{H} 3$ = Terdapat pengaruh religiusitas (X1) dan lokasi (X2) secara simultan terhadap keputusan memilih KPR Syariah (Y)

\section{METODE PENELITIAN}

Pendekatan yang digunakan dalam penulisan ini adalah pendekatan kuantitatif, karena data yang akan dianalisis dalam penelitian ini berbentuk angka dan menggunakan analisis statistic. Penelitian ini berlokasi di Jl. Wolter Monginsidi No. 133 C Kota Palu, Kecamatan Palu Selatan, Provinsi Sulawesi Tengah.

Populasi merupakan keseluruhan unsur-unsur yang memiliki satu atau beberapa cirri atau karakteristik yang sama. ${ }^{3}$ Populasi dari penelitian ini adalah nasabah BRI Syariah KC Palu sebanyak 6.741 nasabah.

Sedangkan sampel adalah bagian dari jumlah dan karakteristik yang dimiliki oleh populasi. Sedang kanteknik sampling merupakan teknik pengambilan sampel. Untuk menetukan besarnya sampel, peneliti menggunakan rumus dengan Metode Slovin. ${ }^{4}$ Berdasarkan rumus tersebut maka diperoleh sampel dalam penelitian ini sebanyak 84 nasabah BRI Syariah KC Palu yang menggunakan produk KPR Syariah 542 dari 6.741 yang menjadi populasi.

Metode dalam pengambilan sampel adalah teknik probability sampling yaitu teknik pengambilan sampel yang memberikan peluang yang sama bagi setiap unsur (anggota) populasi untuk dipilih menjadi anggota sampel dengan cara simple random sampling dimana peneliti mengambil anggota sampel dari populasi dilakukan secara acak tanpa memperhatikan strata yang ada dalam populasi. ${ }^{5}$

${ }^{3}$ Sugiyono, MetodePenelitian Pendidikan PendekatanKuantitatif, Kualitatif, dan $R$ dan D.(Cet. 20,Bandung: Alfabeta, 2014), 297.

${ }^{4}$ Muhammad, MetodePenelitianEkonomi Islam PendekatanKuantitatif (Cet. I, Jakarta: Rajawali Pers, 2008), 180.

${ }^{5}$ Syofian Siregar, Statistika Deskriptif untuk Penelitian (Ed. I,Cet.I, Jakarta: PT. RajaGrafindo Persada,2010),145. 
Data dikumpul dengan cara membagi survey kepada sampel yang telah dipilih. Sedangkan hasil survey diolah dengan menggunakan SPSS.

\section{HASIL DAN PEMBAHASAN}

\subsection{DeskripsiResponden dan Kuesioner}

Penelitian ini dilakukan pada perumahan pembiayaan BRI Syariah KC Palu Wolter Monginsidi. Data penelitian menggunakan instrumen kuesioner yang dibagikan kepada nasabaha pembiayaan KPR syariah BRI Syariah KC Palu Wolter Monginsidi sebagai sampel penelitian. Penyebaran kuesioner disebarkan oleh peneliti kepada sampel yang diteliti dengan perincian seperti dalam tabel berikutini.

Tabel 1. Deskripsi Kuesioner

\begin{tabular}{|c|c|c|c|c|}
\hline $\begin{array}{l}\text { Jumlah } \\
\text { Sampel }\end{array}$ & $\begin{array}{c}\text { Kuesioner } \\
\text { Disebar }\end{array}$ & $\begin{array}{c}\text { Kuesioner } \\
\text { Kembali }\end{array}$ & $\begin{array}{c}\text { Kuesioner } \\
\text { Diolah }\end{array}$ & $\begin{array}{c}\text { Persen- } \\
\text { tase }\end{array}$ \\
\hline 84 & 84 bundel & 84 bundel & 84 bundel & $100 \%$ \\
\hline
\end{tabular}

Responden penelitian berjumlah 84 orang yang dipilih secara acak. Jumlah responden tersebut terdiri dari 36 orang lakilaki dan 48 orang perempuan. Karakteristik responden dapat dijelaskan pada table 2 . Berikut ini.

Tabel2. Karakteristik Responden

\begin{tabular}{|c|c|c|}
\hline Jenis Kelamin & Responden & Persentase(\%) \\
\hline Laki-laki & 36 & 42.9 \\
\hline Perempuan & 48 & 57.1 \\
\hline Jumlah & 84 & 100 \\
\hline
\end{tabular}

Sumber : hasil penelitian
Pada tabel 2 diatas menunjukkan bahwa dari 84 orang sampel dalam penelitian ini yang berjenis kelamin laki-laki berjumlah 36 orang (42.9\%) dan yang berjenis kelamin perempuan 48 orang (57.1\%). Sehingga nampak disini bahwa sebagian besar sampel penelitian ini berjenis kelamin perempuan.

\subsection{Uji Validitas dan Reliabilitas}

Dengan menggunakan instrumen yang valid dan realibel dalam pengumpulan data, maka diharapkan hasil penelitian akan menjadi valid dan realibel. Jadi instrumen valid dan realibel merupakan syarat mutlak untuk mendapatkan hasil penelitian yang valid dan realibel. Hal ini tidak berarti bahwa dengan menggunakan instrumen yang telah teruji validitas dan realibitasnya, otomatis hasil (data) penelitian menjadi valid dan realibel. Hal ini masih akan di pengaruhi oleh kondisi objek yang di teliti, dan kemapuan orang yang menggunakan instrument untuk mengumpulkan data.

Instrumen yang dinyatakan valid dan realibel adalah; instrumen yang valid, berarti alat ukur yang digunakan untuk mendapatkan data (mengukur) itu valid. Valid berarti instrument tersebut dapat digunakan untuk mengukur apa yang seharusnya diukur. Sedangkan instrumen yang realibel berarti bila digunakan untuk 
mengukur berkali-kali akan menghasilkan data yang sama.

a. Uji Validitas

Uji validitas yaitu mengkorelasikan masing-masing pernyataan dengan jumlah skor untuk masing-masing variabel. Syarat minimum untuk memenuhi syarat adalaha pabila $\mathrm{r}=0,3$ jadi apabila korelasi antar butir dengan skor total kurang dari 0,3 maka instrument tersebut tidak valid. ${ }^{6}$

Tabel 3. Hasil Uji Validitas

\begin{tabular}{|c|c|c|c|c|}
\hline Variabel & $\begin{array}{c}\text { Item } \\
\text { Pernyataan }\end{array}$ & $\begin{array}{c}\text { Corrected } \\
\text { Item Total } \\
\text { Correlation }\end{array}$ & $\begin{array}{c}\mathrm{R} \\
\text { Kritis }\end{array}$ & Keterangan \\
\hline Religiusitas & 1 & 0.372 & 0.3 & Valid \\
(X1) & 2 & 0.733 & 0.3 & Valid \\
& 4 & 0.655 & 0.3 & Valid \\
& 5 & 0.668 & 0.3 & Valid \\
& 1 & 0.362 & 0.3 & Valid \\
Lokasi (X2) & 2 & 0.578 & 0.3 & Valid \\
& 3 & 0.726 & 0.3 & Valid \\
& 4 & 0.393 & 0.3 & Valid \\
\hline Keputusan & 1 & 0.459 & 0.3 & Valid \\
Memilih & 2 & 0.616 & 0.3 & Valid \\
KPR Syariah & 3 & 0.696 & 0.3 & Valid \\
(Y) & 4 & 0.540 & 0.3 & Valid \\
Sumber data : Output SPSS 21,0 &
\end{tabular}

Berdasarkan tabel 3 diatas hasil uji validitas, maka dapat dinyatakan bahwa semua instrument layak ikut sertakan dalam penelitian ini, karena koefisien korelasi (rhitung) seluruh item pernyataan yang diperoleh lebih besar dari nilai r-kritis yaitu 0,30 .

\section{b. Uji Reliabilitas}

${ }^{6}$ Sugiyono, MetodePenelitianKuantitatif, Kualitatif dan $R$ an D, (Cet.XIII, Bandung: CV. Alfabeta, 2011), 20.
Setelah instrument dalam penelitian ini dinyatakan valid, maka selanjutnya perlu dilakukan uji reliabilitas atau uji keandalan instrument penelitian.

Pengujian reliabilitas dilakukan dengan internal consistency atau derajat ketepatan jawaban. Untuk penelitian ini digunakan Statistical Packaged For social Sciences (SPSS) sebagai alternative pengujian reliabilitas untuk mengetahui konsistensi hasil sebuah jawaban tentang tanggapan responden. Untuk melakukan pengujian reliabititas penulis menggunakan SPSS versi 21, yaitu dalam mengukur reliabilitas disini menggunakan uji statistic Cronbach Alpha $(\alpha)$, yang mana satu variabel dikatakan reliable jika memiliki Cronbach Alpha lebih dari 0,60 (>0,60). ${ }^{7}$

$$
\text { Hasil pengujian reliabilitas }
$$
instrument menggunakan alat bantu oleh statistik SPSS versi 21.0 for windows dapat diketahui dalamta belberikut:

Tabel4. Hasil Uji Validaitas

\begin{tabular}{|c|c|c|c|}
\hline Variabel & $\begin{array}{r}\text { Reliability } \\
\text { Coeficiens }\end{array}$ & $\begin{array}{c}\text { Cronbach } \\
\text { alpha }\end{array}$ & Keterangan \\
\hline Religiusitas (X1) & 5 Item & 0,760 & Realibel \\
\hline Lokasi (X2) & 4 Item & 0,712 & Realibel \\
\hline $\begin{array}{c}\text { Keputusan Memilih } \\
\text { KPR Syariah (Y) }\end{array}$ & 4 Item & 0,771 & Realibel \\
\hline
\end{tabular}

Berdasarkan pada tabel 4.5 tersebut tampilan SPSS menunjukan bahwa nilai Cronbanch Alpha> 0,60 yang menurut 
kriteria sebelumnya bisa dikatakan reliabel, sehingga dapat disimpulkan sesuai item pernyataan dari variabel $\mathrm{X}$ dan $\mathrm{Y}$ dapat diuji lebih lanjut.

\subsection{Hasil PengujianHipotesis}

a. Uji Simultan (UjiF)

Uji simultan digunakanuntuk menguji apakah variabel independen (X) benar-benar memberikan kontribusi terhadap variabel (Y). Dalam pengujian ini ingin diketahui apakan variabel independen (X) secara bersama-sama meberikan kontribusi secara signifikan terhadap variabel dependen $(\mathrm{Y})$.

Tabel 4. Hasil Uji Simulasi (Uji F)

\begin{tabular}{|ll|c|r|r|c|c|}
\hline \multicolumn{2}{|l|}{ Model } & $\begin{array}{l}\text { Sum of } \\
\text { Squares }\end{array}$ & Df & $\begin{array}{r}\text { Mean } \\
\text { Square }\end{array}$ & F & Sig. \\
\hline 1 & Regression & 195.891 & 2 & 97.945 & 26.729 & $.000^{\mathrm{b}}$ \\
& Residual & 296.812 & 81 & 3.664 & & \\
& Total & 492.702 & 83 & & & \\
\hline
\end{tabular}

a. Dependent Variable: Keputusan Memilih KPRSyariah (Y)

b. Predictors: (Constant), Lokasi (X2), Religiusitas (X1)

Berdasarkan hasil ujiANOVA (Analysis of Varians) atau $\mathrm{F}$ test diketahui nilai signifikansi untuk pengaruh religiusitas dan lokasi secara simultan terhadap keputusan memilih KPRSyariah sebesar $0.000<0.05$ dan nilai $F_{\text {hitung }} 26.729>$. $F_{\text {tabel }}$ 3.11, sehingga dapat disimpulkan bahwa $\mathrm{H} 3$ diterima yang berarti terdapat pengaruh religiusitas (X1) dan lokasi (X2) secara simultan terhadap keputusan memilih KPRSyariah (Y).

\section{b. KoefisienDeterminasi}

Analisiskoefesien determinasi dilakukan untuk mengetahui seberapa besar nilai persentase kontribusi variabel bebas terhadap variabel terikat berikut. Dari hasil perhitungan melalui alat ukur statistic SPSS 21.0 for Windows di dapatkan nilai koefesien determinasi sebagai berikut:

Tebl 5. Hasil Uji Koefesien Determinasi

\begin{tabular}{|l|c|r|r|r|r|}
\hline Model & $\mathrm{R}$ & $\begin{array}{r}\mathrm{R} \\
\text { Square }\end{array}$ & $\begin{array}{c}\text { Adjusted R } \\
\text { Square }\end{array}$ & $\begin{array}{l}\text { Std. Error of } \\
\text { the Estimate }\end{array}$ & $\begin{array}{c}\text { Durbin- } \\
\text { Watson }\end{array}$ \\
\hline 1 & $.631^{\mathrm{a}}$ & .398 & .383 & 1.914 & 1.914 \\
\hline
\end{tabular}
a. Predictors: (Constant), Lokasi (X2), Religiusitas (X1)
b. Dependent Variable: Keputusan Memilih KPRSyariah (Y)

Dari tampilan output SPSS model summary besarnya R Square adalah0.398 hal ini berarti bahwa variasi perubahan variabel keputusan memilih KPRSyariah (Y) dipengaruhi oleh perubahan variabel religiusitas (X1), lokasi (X2), sebesar 39.8\%. Sedangkan sisanya $(100 \%-39.8 \%=60.2 \%)$ dipengaruhi oleh faktor lain diluar penelitian ini.

\subsection{Pembahasan}

Religiusitas menjadi salah satu pertimbangan pemilihanKPR syariah oleh beberapa orang disebabkan oleh pengaruh kepercayaan, mayoritas penduduk asli Indonesia termasuk kota Palu beragama Islam, sehingga kiranya sangat prospek untuk melakukan suatu bisnis yang berlandaskan syariah. Menurut Glock dan R. Stark hal ini sesuai dengan lima dimensi religiusitas dalam diri manusia, yaitu: ${ }^{6}$

a. Dimensi keyakinan/ ideologi (Religius 
Believe)

Dimensi ini menunjukkan pada seberapa tingkat keyakinan muslim terhadap kebenaran ajaran-ajaran agama, terutama yang bersifat fundamental dan dogmatik. Dimensi praktik (Religius Ractice). Dimensi ini berkaitan dengan komitmen dan ketaatan terhadap agama yang dianutnya, yang diwujudkan dalam ritual atau peribadatan. Dimensi ini dibagi menjadi dua, yaitu:

1) Ritual, mengacu pada seperangkat tindakan keagamaan formal dan praktikpraktik suci yang mengharapkan pemeluknya melaksanakan.

2) Ketaatan, ketaatan dan ritual bagaikan ikan dan air. Ketika seseorang telah mengetahui ritual-ritual yang harus dilakukan, maka dapat mungkin ritual itu dilakukan semaksimal mungkin untuk menunjukkan bahwa "saya adalah orang yang taat dan komit padaagama."

b. Dimensi pengalaman (ReligiusFeeling)

Dimensi ini berkaitan dengan seberapa besar tingkat seseorang dalam merasakan pengalaman-pengalaman religinya.

c. Dimensi pengetahuan agama (Religius Knowlage)

Dimensi ini menunjukkan pada tingkat pengetahuan dan pemahaman muslim pada ajaran ajaran agamanya, terutama ajaranajaran pokok yang bermuat dalam Al-Qur'an a. Dimensi konsekuensi (ReligiusEffect)
Dimensi ini menunjuk pada seberapa besar perilaku muslim dipengaruhi oleh ajaran-ajaran agama.

Berdasarkan hasil pengujian dapat diketahui dari tabel Coefficients variabel religiusitas (X1) berpengaruh positif dan signifikan terhadap keputusan memilih KPR Syariah (Y). Dengan nilai signifikan $0.000<$ 0.05. Maka dari pembahasan ini menunjukkan bahwa variabel religiusitas mempengaruhi keputusan nasabah memilih BRI Syariah dalam transaksi KPR syariah.

Hal ini didukung oleh penelitian Kevin Pri Riandi bahwa religiusitas berpengaruh positif dan signifikan terhadap keputusan nasabah dalam pemilihan KPR syariah. Hal ini diperlihatkan oleh tingkat religiusitas yang memiliki tingkat signifikansi sebesar 0.020. Dari hasil uji $\mathrm{t}$ pada variabel kemudahan menyatakan bahwa signifikansi uji t lebih kecil dari 0.05. Berdasarkan hasil tersebut maka hipotesis yang menyatakan religiusitas berpengaruh positif dan signifikan terhadap keputusan nasabah dalam pemilihan KPR Syariah. Dalam penelitian ini variabel independennya adalah religiusitas, ekonomi, pelayanan dan pemasaran. Dengan demikian dalam penelitian tersebut secara parsial, religiusitas berpengaruh signifikan terhadap keputusan nasabah dalam pemilihan KPR Syariah pada Bank BTN Syariah Yogyakarta. ${ }^{7}$ c. Pengambilan Keputusan 
Menurut Kotler dan Armstrong dalam bukunya yang berjudul Marketing Management, bauran pemasaran atau marketing mix adalah perangkat alat pemasaran taktis yang dapat dikendalikan, produk (product), harga (price), distribusi (place) dan promosi (promotion). ${ }^{8}$ Dalam memilih KPR syariah tentu saja lokasi (place) juga sebagai bahan pertimbangan untuk memperkuat keputusan pembelian. Dekat dengan kawasan industri, memiliki fasilitas lengkap dan lainnya menjadi prioritas bagi masyarakat untuk memilih lokasi strategis sesuai kebutuhan yang diinginkan.

Lokasi merupakan faktor terpenting yang mempengaruhi sebuah permintaan rumah, pada hakikatnya merupakan hipotesis yang menyatakan semakin strategis letak rumah tersebut berarti semakin baik, maka makin banyak permintaan. Salah satu faktor yang mempengaruhi pembeli untuk membeli perumahan adalah letak perumahan tersebut. Dengan mempertimbangkan akses jalan yang cepat dan mudah, dekat dengan pasar kota, transportasi mudah, bebas banjir merupakan suatu contoh mengapa faktor lokasipenting. ${ }^{9}$

Berdasarkan hasil pengujian dapat diketahui dari tabel coefficient variabel lokasi (X2) berpengaruh positif dan signifikan terhadap keputusan memilih KPRSyariah. Dengan nilai signifikan $0.001<$
0.05. Maka dari pembahasan ini menunjukkan bahwa variabel lokasi mempengaruhi keputusan nasabah memilih BRISyariah dalam transaksi KPRsyariah.

Hal ini didukung oleh penelitian Winda Annisa Cahya bahwa lokasi berpengaruh positif dan signifikan terhadap keputusan nasabah mengambil KPR syariah. Hal ini diperlihatkan oleh tingkat lokasi yang memiliki tingkat signifikansi sebesar 0.000 . Dari hasil uji t pada variabel kemudahan menyatakan bahwa signifikansi uji t lebih kecil dari 0.05. Sedangkan nilai t- hitung yang diperoleh yaitu 5.666 lebih besar dari nilai t-tabel yaitu 1.980. Berdasarkan hasil tersebut maka hipotesis yang menyatakan lokasi berpengaruh positif dan signifikan terhadap keputusan nasabah dalam pemilihan KPR Syariah. Dalam penelitian ini variabel independennya adalah lokasi, harga dan citra merek. Dengan demikian dalam penelitian tersebut secara parsial, lokasi berpengaruh signifikan terhadap keputusan nasabah mengambil Kredit Kepemilikan Rumah (KPR) Syariah pada Bank BTN SyariahSurakarta. ${ }^{10}$

\section{KESIMPULAN}

Berdasarkan hasil penelitian dan analisis data yang telah diuraikan pada hasil dan pembahasan sebelumnya, maka dapat diambil kesimpulan hasil penelitian sebagai berikut: 
Religiusitas berpengaruh positif dan signifikan terhadap keputusan nasabah memilih BRI Syariah dalam transaksi KPR syariah. Hal ini dapat dilihat dari penelitian yang telah diteliti oleh peneliti menunjukkan bahwa dari hasil uji $\mathrm{t}$ diperoleh nilait $_{\text {hitung }}>\mathrm{t}_{\text {tabelyaitu4.673 }}>1.993$ dengannilaip robabilitas sebesar 0.000 berarti lebih kecil dari 0.05 maka $\mathrm{H} 1$ diterima. Yang artinya religiusitas berpengaruh positif signifikan terhadap keputusan nasabah memilih BRI Syariah KC Palu Wolter Monginsidi dalam transaksi KPR syariah.

Lokasi berpengaruh positif dan signifikan terhadap keputusan nasabah memilih BRI Syariah dalam transaksi KPR syariah. Hal ini dapat dilihat dari penelitian yang telah diteliti oleh peneliti menunjukkan bahwa dari hasil uji t diperoleh nilai $t_{\text {hitung }}>$ $\mathrm{t}_{\text {tabel }}$ yaitu $3.348>1.993$ dengan nilai probabilitas sebesar 0.001 berarti lebih kecil dari 0.05 maka H2 diterima. Yang artinya lokasi berpengaruh positif signifikan terhadap keputusan nasabah memilih BRI Syariah KC Palu Wolter Monginsidi dalam transaksi KPRsyariah.

Religiusitas dan lokasi berpengaruh simultan dan signifikan terhadap keputusan nasabah memilih BRI Syariah dalam transaksi KPR syariah. Hal ini dapat dilihat dari penelitian yang telah diteliti oleh peneliti menunjukkan bahwa dari hasil uji $\mathrm{F}$ diperoleh nilai $F_{\text {hitung }}>F_{\text {tabel }}$ yaitu $26.729>$
3.11 dengan nilai probabilitas sebesar 0.000 berarti lebih kecil dari 0.05 maka H3 diterima. Yangartinyareligiusitas dan lokasi berpengaruh secara simultan dan signifikan terhadap keputusan nasabah memilih BRI Syariah KC Palu Wolter Monginsidi dalam transaksi KPR syariah

\section{Daftar Pustaka}

Abdullah, Thamrin dan Francis Tantri. 2013. Manajemen Pemasaran. Jakarta: PT RajaGrafindo Persada.

Ascarya. 2011. Akad dan Produk Bank Syariah. Jakarta: PT RajaGrafindo Persada Asro, Muhammad dan Muhammad Kholid. 2011. Fiqh Perbankan. Bandung: Pustaka Setia.

Assauri, Sofjan .2013. Manajemen Pemasaran. Jakarta: Rajawali Pers.

Badan Pengembangan dan Pembinaan Bahasa Kementrian Pendidikan dan Kebudayaan. 2011. Kamus Bahasa Indonesia untuk Pelajar. Jakarta: Badan Pengembangan dan Pembinaan Bahasa.

Bakhtiar, Amsal. 2012. Filsafat Agama. Jakarta: Rajawali Pers

Bungin, M. Burhan. 2005. Metodologi Penelitian Kuantitatif Komunikasi, Ekonomi, dan Kebijakan Publik Serta Ilmu-ilmu Sosial lainnya. Eds. 2. Jakarta: Kencana Prenadamedia Group.

Dadang, Kahmad. 2009. Sosiologi Agama. Bandung: PT Remaja Rosda Karya.

Departemen Agama RI. 2002. Al-Qur'an dan Terjemahannya. Jakarta: AlHidayah

Surabaya.

Firdaus, Rachmat dan Maya Ariyanti. 2009. Manajemen Perkreditan Umum. Bandung: Alfabeta.

Ghafu, M. 2004. Analisis Faktor-faktor yang Mempengaruhi Jumlah Simpanan Nasabah di Bank Syariah (Studi Kasus 
Bank Muamalat Indonesia). Dalam Aplikasia Jurnal Ilmu-ilmu Agama. Vol. V. No.2. Yogyakarta: Pusat Pengabdian Kepada Masyarakat (PPM) UIN Sunan Kalijaga Yogyakarta.

Ghozali, Imam Ghozali. 2013. Aplikasi Analisis Muktivariate, dengan Program IBM SPSS 21. Eds. 7. Semarang: Badan Penerbit Universitas Diponegoro.

Hamzah, Andi, I Wayan Suandra, B.A. Manalu. 2000. Dasar-dasar Hukum Perumahan. Jakarta: PT Rineka Cipta.

Ifham, Ahmad. 2015. Ini Lho Bank Syariah! Memahami Bank Syariah Dengan Mudah. Jakarta: PT Gramedia.

Karim, Adiwarma A. 2007. Bank Islam: Analisis Fiqih dan Keuangan. Eds.3. Jakarta: PT. RajaGrafindo Persada.

Kasmir. 2016. Bank dan Lembaga Keuangan Lainnya. Eds. Revisi. Cet. 17. Jakarta: Rajawali Pers.

-----. 2008. Pemasaran Bank. Cet. 3. Jakarta: Kencana Prenada Media Group. Kotler, Philip. 2010. Manajemen Pemasaran, Eds. 13 Bahasa Indonesia, Jilid 1 dan 2. Jakarta: Erlangga.

Latan, Hengky. 2014. Aplikasi Analisis Data Statistik Untuk Ilmu Sosial Sains dengan IBM SPSS. Bandung:Alfabeta.

Lewis, Mervyn K dan Latifa M. Algaoud. 2001. Perbankan Syariah: Prinsip, Praktik, dan Prospek. Jakarta: PT Serambi IlmuSemesta.

Martono, Nanang. 2016. Metode Penelitan Kuantitatif Analisis Isi dan Analisis Data Sekunder. Cet. IV. Jakarta: PT. GrafindoPersada.

------. 2012. Metode Penelitian Kuantitatif Analisis Isi dan Analisis Data Sekunder. Eds. Revisi. Cet. 3. Jakarta: Rajawali Pers.

Nasution, Harun. 1985. Islam Ditinjau dari Berbagai Aspeknya. Cet. 5. Jakarta: Universitas Indonesia (UI-Press).
Nasution, S. 2014. Metode Research (Penelitian Ilmiah). Cet. 14. Jakarta: Bumi Aksara.

Nurdin, N., Novia, N., Rahman, A., \& Suhada, R. (2019). Potensi Industri Produk Makanan Halal Di Kota Palu. Jurnal Ilmu Ekonomi dan Bisnis Islam, 1(1), 1-12.

Nurdin, N., \& Yusuf, K. (2020). Knowledge management lifecycle in Islamic bank: the case of syariah banks in Indonesia. International Journal of Knowledge Management Studies, 11(1), 59-80. doi: 10.1504/ijkms.2020.105073

Prasetijo, Ristiyanti dan John J.O.I Ihalauw. 2005. Perilaku Konsumen. Yogyakarta: Andi Yogyakarta.

Purwanto, Yadi. 2006. Psikologi Islam. Bandung: PTRefika Aditama.

Ridwan. 2012. Penelitian untuk Guru, Karyawan dan Peneliti. Bandung: Alfabeta. Sarjono, Haryadi dan Winda Julianti. 2011. SPSS vs Lisrel Sebuah Pengantar, Aplikasi Untuk Riset. Jakarta: Salemba Empat.

Setiadi, Nugroho J. 2010. Perilaku Konsume., Eds. Revisi. Cet. 4. Jakarta: Kencana Prenada Media Group.

Sugiyono. 2011. Metode Penelitian Kuantitatif Kualitatif dan $R \& D$. Cet. XIX. Bandung: CV. Alfabeta.

-----. 2014. Cara Mudah Menyusun: Skripsi, Tesis, dan Disertasi. Cet II. Bandung: Alfabeta.

Sujarweni, V. Wiratna. 2014. Metodologi Penelitian (Lengkap, Praktis, dan Mudah Dipahami. Yogyakarta: Pustaka Baru Pres.

Sujianto, Agus Eko. 2009. Aplikasi Statistik dengan SPSS 16.0. Jakarta: PT. Prestasi Pustaka.

Sulaiman, Wahid. 2010. Analisis Regresi Menggunakan SPSS: Contoh Kasus dan Pemecahannya. Yogyakarta: Andi. 
Suliyanto. 2011. Ekonometrika Terapan, Teori dan Aplikasi Dengan SPSS. Yogyakarta: CV Andi Offset.

Sumarwan, Ujang. 2008. Perilaku Konsumen Teori dan Penerapannya dalam Pemasaran. Jakarta: PT. Gramedia Utama.

Supardi. 2005. Metode Penelitian Ekonomi \& Bisnis. Yogyakarta: UII Press.

Sunyoto, Danang. 2011. Analisis Regresi dan Uji Hipotesis. Yogyakarta: CAPS. SyofianSiregar. 2010. Statistika Deskriptif untuk Penelitian:

Dilengkapi Perhitungan Manual dan Aplikasi SPSS Versi 17. Eds. 1. Jakarta: PT RajaGrafindo Persada.

Taniredja, Takiran dan Hidayat Mustfida. 2013. Penilitian Kuantitatif. Purwekerto: Alfabeta.

Usman, Husaini dan R. Purnomo Setiady Akbar. 2006. Pengantar Statistika. Eds. 2.

Jakarta: PT Bumi Aksara.Wangsawidjaja Z.A. 2012. Pembiayaan Bank Syariah. Jakarta: PT Gramedia. Admin. BRISyariah.

https://www.brisyariah.co.id>detailPro duk. diakses pada 22 Mei 2019.

Admin. Tata cara perencanaan lingkungan. http://www.scribd.com/mobile/doc/SN I-03-1733-2004-Tata-Cara-

Perencanaan-Lingkungan-Perumahan. diakses: 31 Januari 2019.

Amri, Kharisma Faundria Amri. "Analisis Faktor-faktor yang Mempengaruhi Nasabah dalam Pemilihan KPR Syariah: Studi Kasus Bank Muamalat Indonesia, TBK". Skripsi. https://www.lib.ui.ac.id. diakses 28 Desember 2018.

Kementrian PUPR. KPBU Perumahan Menjadi Alternatif Pembiayaan Perumahan Layak dan Terjangkau. https://www.pu.go.id/. diakses pada 24 Desember 2018.

Kurniawati, Winda Annisa Cahya. "Pengaruh Lokasi Perumahan, Harga Perumahan dan Citra Merek Terhadap Keputusan Nasabah Mengambil Kredit
Kepemilikan Rumah (KPR) Syariah (Studi Kasus Nasabah BTN Syariah Surakarta)". Skripsi. https://www.eprints.iainsurakarta.ac.id. diakses pada: 29 Desember 2018.

Riandi, Kevin Pri. Faktor-faktor yang Mempengaruhi Nasabah dalam Pemilihan KPR Syariah (Studi kasus pada Bank BTN Syariah Yogyakarta). Skripsi. $\quad$ https://www.digilib.uinsuka.ac.id. diakses pada: 24 Desember2018. 
